Indonesian Journal of Cardiology

Indonesian J Cardiol 2018:39:1 10-119

pISSN: 0I 26-3773 / elSSN: 2620-4762

doi: $10.3070 \mid /$ ijc.v39i3.802

\title{
Hypoxic Preconditioning Effect on Senescence Cell Process in Cultured Adipose-Derived Mesenchymal Stem Cells (AMSCs)
}

\author{
Nadiar Dwi Nuarisa 1, I Gde Rurus Suryawan 1, Andrianto '
}

IDepartment of Cardiology and Vascular Medicine, Faculty of Medicine Airlangga University, RSUD dr.

Soetomo Surabaya

Correspondence: Nadiar Dwi Nuarisa, MD. Department of Cardiology and Vascular Medicine, Faculty of Medicine Airlangga University,

RSUD dr. Soetomo Surabaya E-mail : nadiardwi@gmail. com

\begin{abstract}
Introduction: Stem cell therapy for myocardial regeneration is expected to increase cardiomyocyte proliferation and trigger neovascularization to improve cardiomyocytes. Mesenchymal Stem Cells (MSCs) are ideal candidates for regenerative medicine and immunotherapy. But low viability of MSCs is a major challenge in this alternative therapy. Therefore, a cytoprotective strategy is needed, one of them is hypoxic preconditioning which can significantly increase survival stem cells after being transplanted. MSCs are known to have a limited life span, after experiencing several splits MSC will enter the senescence process. It is known that hypoxia can also increase cell proliferation and differentiation potential in vitro and in vivo through the role of Octamer-4 (Oct-4) as a regulator of the pluripotency gene. Methods: Experimental laboratory studies (in vitro studies) using human-AMSCs which were given hypoxic preconditioning, observed as a immunocytochemistry. Results: The results showed that hypoxic precondition ( $1 \%$ O2) inhibited the senescence process. It can be seen in the lower expression of senescence in hypoxic conditions at P6, P7, P8, P9, PI0 compared to normoxic $((p=0,004, p=0,001$, $p=0,009, p=0,013, p=0,024$. There is a significant difference in the senescence expression of each passage in hypoxic and normoxic conditions with the highest expression at PIO. In addition, we also observed AMSCs differentiation through the Oct-4 expression. It is showed that Oct-4 expression were higher in hypoxia compared to normoxia on P7, P8, P9, PIO ( $p=0,009, p=0,009, p=0,030, p=0,000 I)$. Conclusions: Hypoxic preconditioning have the effect of inhibiting the senescence process on Adipose-derived MSCs (AMSCs) or prolonging their life span. The longer life span of AMSCs is also seen by higher cell differentiation potential from increased expression of Oct-4. However, the mechanism of inhibiting the senescence process in hypoxia in stem cells is still remain unknown.
\end{abstract}

(Indonesian J Cardiol. 20 I8;39: I 10-I I9)

Keywords: human-Adipose derived Mesenchymal Stem Cell Cultures (h-AMSCs), Hypoxic Preconditioning, Senescence cell, Oct-4. 


\title{
Pengaruh Prakondisi Hipoksia Terhadap Proses Senescence Sel pada Kultur Adipose-Derived Mesenchymal Stem Cells (AMSCs)
}

\author{
Nadiar Dwi Nuarisa 1, I Gde Rurus Suryawan 1, Andrianto ${ }^{1}$
}

\begin{abstract}
Abstrak
Pendahuluan: Terapi stem cells untuk regenerasi miokard diharapkan dapat meningkatkan proliferasi kardiomiosit dan memicu neovaskularisasi untuk perbaikan kardiomiosit. Mesenchymal Stem Cells (MSCs) adalah kandidat ideal untuk pengobatan regeneratif dan imunoterapi. Tetapi viabilitas MSCs yang cukup rendah merupakan tantangan utama dalam terapi alternatif ini. Oleh karena itu diperlukan suatu strategi sitoprotektif, salah satunya berupa prakondisi hipoksia yang secara signifikan dapat meningkatkan survival stem cells setelah ditransplantasikan. MSCs diketahui memiliki masa hidup yang terbatas, setelah mengalami beberapa kali pembelahan MSC akan memasuki proses senescence. Diketahui bahwa hipoksia juga dapat meningkatkan potensi proliferasi dan diferensiasi sel in vitro dan in vivo melalui peran dari Octamer-4 (Oct-4) sebagai pengatur gen pluripotensi.

Metode : Studi laboratorium eksperimental (studi in vitro) menggunakan AMSCs manusia yang diberi prakondisi hipoksia, diamati secara imunositokimia.

Hasil: Hasil penelitian menunjukkan bahwa prakondisi hipoksia (O2 1\%) menghambat proses senescence. Dapat dilihat pada ekspresi senescence yang lebih rendah pada kondisi hipoksia pada P6, P7, P8, P9, P10 dibandingkan normoksia $(p=0,004, p=0,001, p=0,009$, $p=0,013, p=0,024)$. Terdapat perbedaan bermakna ekspresi senescence tiap masing-masing pasase di kondisi hipoksia maupun normoksia dengan ekspresi yang tertinggi adalah saat P10. Selain itu, kami juga melakukan pengamatan diferensiasi AMSCs melalui ekspresi Oct- 4 . Didapatkan hasil berupa ekspresi Oct-4 yang lebih tinggi pada kondisi hipoksia dibandingkan normoksia pada P7, P8, P9, P10 ( $p=0,009$, $p=0,009, p=0,030, p=0,0001$ ).

Kesimpulan: Prakondisi hipoksia menimbulkan efek penghambatan proses senescence pada Adipose-derived MSCs (AMSCs) atau memperpanjang rentang hidupnya. Semakin panjangnya rentang hidup AMSCs ini diperkuat dengan tingginya potensi diferensiasi sel dari peningkatan ekspresi Oct-4. Namun mekanisme terjadinya penghambatan proses senescence dalam hipoksia pada stem cells masih belum diketahui secara pasti.
\end{abstract}

(Indonesian J Cardiol. 2018;39:110-119)

Kata Kunci: human-Adipose Mesenchymal Stem Cell Cultures (h-AMSCs), Prakondisi Hipoksia, Senescence sel, Oct-4.

I Departemen Kardiologi dan Kedokteran Vaskular, Fakultas Kedokteran Universitas Airlangga, RSUD dr. Soetomo Surabaya

Korespondensi:

Nadiar Dwi Nuarisa, MD. Department of Cardiology and Vascular Medicine,

Faculty of Medicine Airlangga University,

RSUD dr. Soetomo Surabaya

E-mail : nadiardwi@gmail.com

\section{Pendahuluan}

$\mathrm{P}$ enyakit kardiovaskuler merupakan salah satu penyebab utama mortalitas dan morbiditas tertinggi di dunia. Penyakit jantung koroner (PJK) merupakan manifestasi klinis utama dari aterosklerosis yang dapat menyebabkan infark miokard. World Health Organization (WHO) memprediksi 
bahwa pada tahun 2020 penyakit aterosklerosis tetap menjadi penyebab utama dari total beban penyakit dan dapat menyebabkan 23 juta mortalitas ${ }^{1,2}$. Di Indonesia sendiri, menurut sensus nasional Depkes tahun 2013 prevalensi penyakit jantung koroner (PJK) sebesar 1,5\% atau sekitar 2,6 juta orang.

Saat penyakit ini berkembang menjadi gagal jantung tahap akhir dengan mortalitas yang tinggi, transplantasi jantung menjadi satu-satunya pilihan terapi. Tetapi, pilihan tersebut sangat terbatas karena hanya sedikit donor jantung dan komplikasi terkait penggunaan obat-obat penekan imun seumur hidup. Maka dari itu, strategi pengobatan terbaru jelas dibutuhkan sebagai alternatif terapi ${ }^{3,4}$. Terapi stem cells telah menunjukkan efek menguntungkan pada beberapa kasus penyakit kardiovaskuler seperti penyakit jantung iskemia, gagal jantung, disfungsi endothelial, penyakit arteri perifer, atherosklerotik dan hipertensi pulmonal5. Tujuan regenerasi miokard atau yang dikenal dengan cardiomyoplasty seluler adalah selain untuk mengganti jaringan miokard yang rusak akibat proses degeneratif, juga untuk menginduksi peningkatan vaskularisasi pada daerah yang mengalami trauma, mencegah remodelling patologis setelah terjadinya atropi ${ }^{6 .}$

Stem cells merupakan sel prekursor jaringan yang memiliki kemampuan untuk memperbaharui diri dan berdiferensiasi menjadi berbagai macam sel. Dengan transplantasi stem cell diharapkan dapat terjadi proliferasi kardiomiosit dan memicu neovaskularisasi untuk perbaikan kardiomiosit. Mesenchymal stem cells (MSCs) merupakan sel yang multipoten yang dapat memperbaharui diri sendiri dan terdapat pada beberapa jaringan dan organ. MSCs banyak menarik perhatian untuk penelitian karena sel ini mudah untuk diisolasi dari aspirat sumsum tulang ataupun jaringan lemak dalam jumlah yang minimal dan dapat dikembangkan untuk kepentingan klinis secara in vitro maupun in $v i v o^{6,7}$. Dari penelitian sebelumnya mengenai viabilitas MSCs yang diinjeksikan kedalam ventrikel kiri dari jantung tikus dewasa strain beige yang dibuat menderita infark miokard sangat rendah, oleh karena MSCs yang diinjeksikan mengalami kematian sel atau apoptosis sebanyak 99\% setelah hari ke-4 pemberian injeksi stem cells $^{8}$.AMSCs memberikan masa depanyang menjanjikan untuk perbaikan dan regenerasi jaringan. Sayangnya, tidak semua MSC yang ditransplantasikan sepenuhnya survive. Diperkirakan akibat kondisi microenvironment pada kondisi iskemia yang menginduksi kematian sel.

Prakondisi hipoksia untuk meningkatkan aktivitas MSCs muncul sebagai alternatif strategi yang lebih aman dan sesuai dengan klinis. Beberapa penelitian membuktikan prakondisi hipoksia sangat efektif untuk proteksi endogenous. Pengaruh dari prakondisi hipoksia juga diteliti pada kultur AMSCs yang menunjukkan peningkatan viabilitas stem cells, dan mengurangi kerusakan sel dan apoptosis pada kondisi iskemik, juga memperbaiki kapasitas angiogenesis9. Prakondisi hipoksia juga dapat meningkatkan survival jaringan setelah iskemia akut melalui aktivasi dari PI3K (phosphatidylinositol 3-kinase)/Akt signalling pathway ${ }^{10}$. PI3K/Akt pathway merupakan survival pathway yang mempunyai peranan penting pada fisiologi dan patofisiologi dari beberapa tipe sel, dengan meningkatkan proliferasi sel, differensiasi dan migrasi sel. Aktivitas Akt dapat meningkatkan proliferasi, angiogenesis, survival, dan migrasi MSC melalui downstream target protein ${ }^{11,12}$.

Senescence adalah keadaan sel yang stabil dan aktif secara metabolik baik in vitro maupun in vivo ditandai dengan terhentinya proliferasi sel secara ireversibel dan terjadi perubahan pada morfologi sel, metabolisme, ekspresi gen dan sekresi fenotip ${ }^{13}$. Senescence pada AMSCs manusia terjadi karena respon terhadap stresor yang berbeda, termasuk stres oksidatif, heat shock, dan agen kemoterapi. Hal ini menunjukkan bahwa jalur aktivasi senescence tidak tergantung pada jaringan narasumber dan rangsangan stres ${ }^{14}$. Berbagai biomarker dipelajari untuk mengkarakterisasi keadaan senescense AMSCs, dimana yang paling sering dihubungkan dengan perubahan morfologi dan proliferatif, peningkatan ekspresi senescence-associated $\beta$-galaktosidase (SA- $\beta$ gal), hilangnya potensi diferensiasi trilinease AMSCs, terhentinya siklus sel, modifikasi epigenetik, stres oksidatif, pemendekan telomere dan kerusakan DNA, aktivasi supresor tumor p53, RB1 dan p16INK415.

Beberapa penelitian menunjukkan bahwa aktivitas lisosomal $\beta$-galaktosidase meningkat cukup banyak pada sel-sel senescence yang dapat dideteksi pada $\mathrm{pH}$ suboptimal 6.0, yang merupakan susasana $\mathrm{pH}$ untuk aktivitas Senescence-Associated $\beta$-Galactosidase (SA$\beta G a l)$. Peningkatan ini nampaknya disebabkan oleh akumulasi peningkatan kadar GLB1 mRNA dan protein. SA- $\beta$ Gal lebih merupakan pengganti marker untuk peningkatan jumlah lisosom atau aktivitasnya, 
yang berhubungan dengan penuaan organisme dan replicative senescence ${ }^{16}$.

Octamer-4 (Oct-4) merupakan suatu protein anggota dari POU (Pit, Oct, Unc) yang terikat pada DNA sebagai faktor transkripsi yang juga dikenal sebagai Oct-3, Okt-3/4, Otf3 atau NF-A3, dikodekan oleh Gen Pou5f1 (terletak di kromosom 6 manusia dan kromosom 17 pada tikus). Oct- 4 berfungsi sebagai pengatur utama kondisi pluripotensial suatu sel. Oct-4, yang ekspresinya terkait dengan sifat pluripotent stem cell merupakan faktor penting yang mengendalikan tahap awal embriogenesis mamalia. Oct-4, Sox 2 dan Nanog bekerjasama untuk mempertahankan self-renewal dan pluripotensial stem cell embrionik manusia dan tikus. Keterlibatan Oct-4 dalam diferensiasi mesendodermal dan hubungan sel jantung dengan stem cell embrionik telah terbukti ${ }^{17}$.

\section{Metode}

Penelitian ini merupakan penelitian eksperimental laboratoris eksploratif (in vitro study) dengan pemberian kondisi hipoksia terhadap kultur adipose-derived mesenchymalstem cell (AMSCs) yang berasal dari jaringan adipocyte. Tujuan dari penelitian ini adalah untuk mengetahui efek prakondisi hipoksia dengan oksigen sebesar 1\% pada kultur adipocyte-derived mesenchymal stem cells (AMSCs) terhadap proses senescence.

Kultur AMSCs yang berada dalam kondisi dorman atau tidur dilakukan aktivasi atau thawing. Tahap kedua, dilakukan penentuan phenotype AMSCs menggunakan metode Imunofluorescene indirect dan flowcytometri yang sesuai dengan kriteria ISCT (International Society of Cellular Therapy). Tahap selanjutnya, sampel AMSCs dibagi menjadi 2 kelompok perlakuan yaitu Kelompok P0 (kontrol) yaitu AMSCs kondisi normoksia (O2 21\%) selama 24 jam, dan Kelompok Perlakuan 1 (P1) yaitu AMSCs kondisi hipoksia (O2 1\%) selama 24 jam. Tahap keempat, sampel pada kelompok hipoksia dan normoksia dipantau manakah yang lebih lambat mencapai proses senescence. Yaitu dengan adanya ekspresi dari SA- $\beta$ Gal secara histokimia menggunakan senescence detection kit (BioVision, USA). Penelitian tahap kelima, Observasi potensi diferensiasi sel dengan ekspresi Oct-4 berdasarkan imunofluoresence (IF) dan imunositokimia. Data yang diperoleh akan diuji secara statistik.

\section{Hasil}

Pemeriksaan flowcytometry dan imunositokimia untuk karakterisasi fenotipe AMSCs menunjukkan ekspresi positif CD44 dan CD90 serta tidak terekspresinya CD45 (Gambar 1), hal ini sesuai dengan kriteria dari ISCT $^{18}$ (Tabel 1).

Table 1. Summary of criteria to identify MSC

1 Adherence to plastic in standard culture conditions

2 Phenotype Positive $(\geq 95 \%+) \quad$ Negative $(\leq 2 \%+)$

CD105 CD45

$\mathrm{CD} 73 \quad \mathrm{CD} 34$

CD90 CD14 or CD11b

CD79 $\alpha$ or CD19

HLA-DR

3 In vitro differentiation: osteoblasts, adipocytes, chondroblasts (demonstrated by staining of in vitro cell culture)

\section{Ekspresi Sel Senescence}

Pada penelitian ini, morfologi sel yang mengalami senescence dapat dilihat dari bentuk spindle like shape
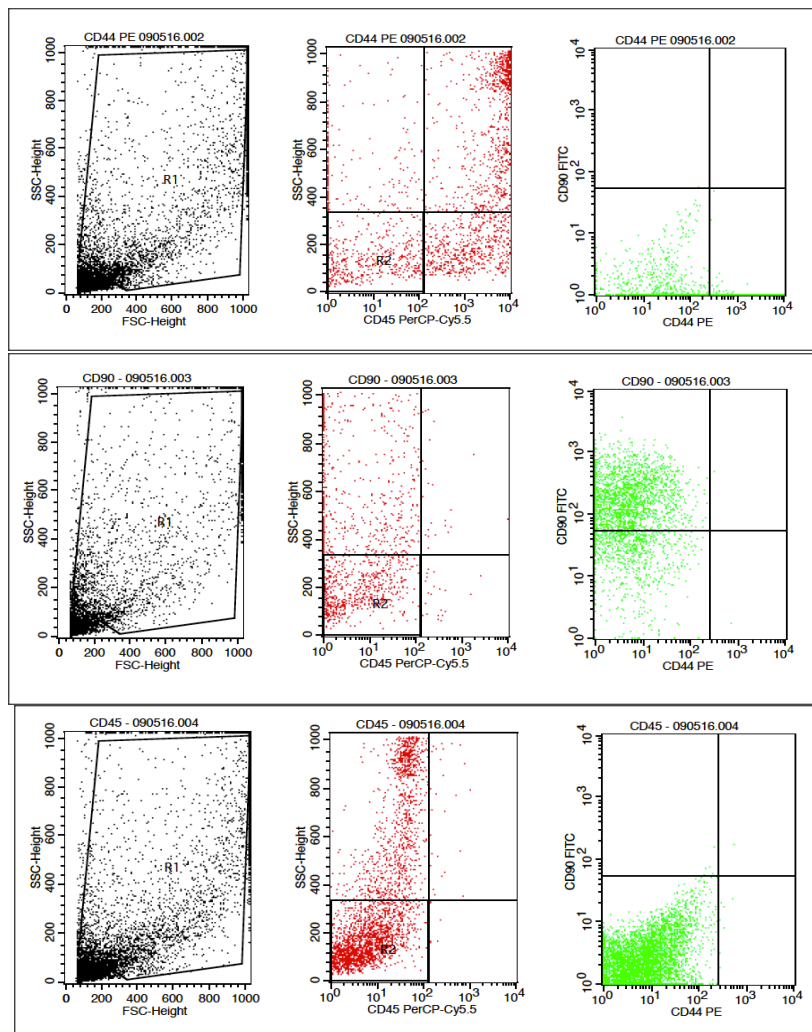

(A) 


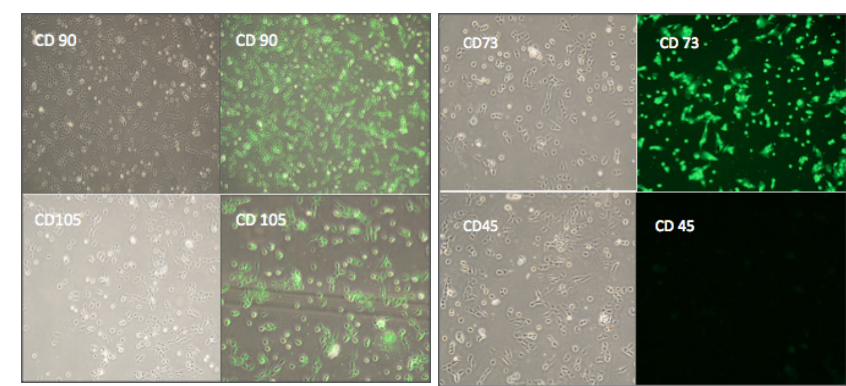

(B)

Gambar 1. Pemeriksaan Flowcytometry (A) menunjukkan ekspresi positif CD44 dan CD90 dan ekspresi negative pada CD45; dan fluorescen imunositokimia (B) menunjukkan sel $\mathrm{CD} 73+\mathrm{CD} 90+, \mathrm{CD} 105$ terekspresi positif dengan pendaran hijau yang kuat dan CD45- yang tidak terekspresi.

AMSCs yang menjadi lebih besar, lebih pipih, dan granularitas yang meningkat serta berwarna biru atau biru kehijauan karena ekspresi dari enzim lisosomal SA- $\beta$ Gal. Pada kondisi hipoksia, ekspresi senescence lebih rendah dibandingkan normoksia pada masingmasing pasase (Tabel 2). Terdapat perbedaan bermakna ekspresi senescence pada kondisi hipoksia dibandingkan normoksia. Semakin lanjut pasase suatu AMSCs, maka warna biru atau biru kehijauan yang menggambarkan ekspresi senescence akan semakin terang (Gambar 2).
Tabel 2. Tabel Deskriptif Ekspresi Sel Senescence

\begin{tabular}{lllll}
\hline \multicolumn{4}{l}{ Ekspresi Sel Senescence } & \\
& Hipoksia & & Normoksia & \\
& Min-Max & Mean \pm SD & Min-Max & Mean \pm SD \\
\hline P6 & $2.37-11.11$ & $3.75 \pm 0.98$ & $5.86-11.11$ & $7.86 \pm 2.10$ \\
P7 & $2.67-10.43$ & $4.31 \pm 1.32$ & $7.10-10.43$ & $8.88 \pm 1.42$ \\
P8 & $4.29-44.39$ & $7.14 \pm 4.05$ & $39.83-44.39$ & $41.71 \pm 1.74$ \\
P9 & $20.98-53.49$ & $28.50 \pm 6.96$ & $36.82-53.49$ & $43.03 \pm 7.47$ \\
P10 & $26.42-83.97$ & $33.43 \pm 4.83$ & $43.78-83.97$ & $55.66 \pm 17.22$ \\
\hline
\end{tabular}

\section{Ekspresi Senescence Hipoksia vs Normoksia}

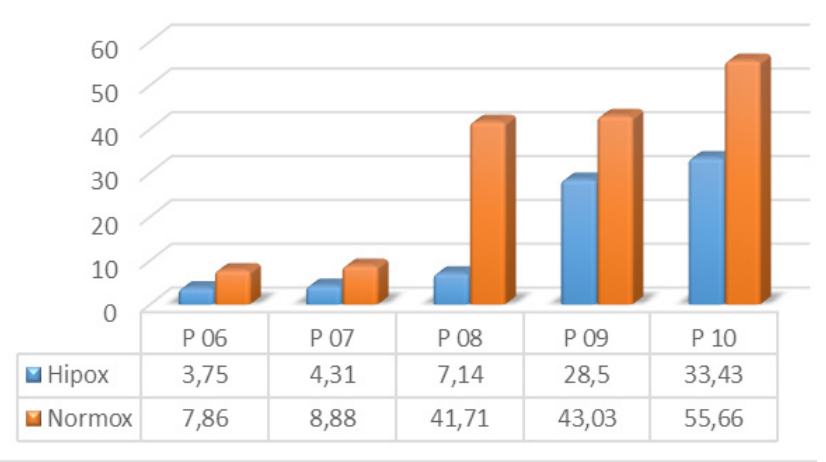

Grafik 1. Perbandingan Ekspresi Senescence Hipoksia dan Normoksia mulai P6 hingga P10
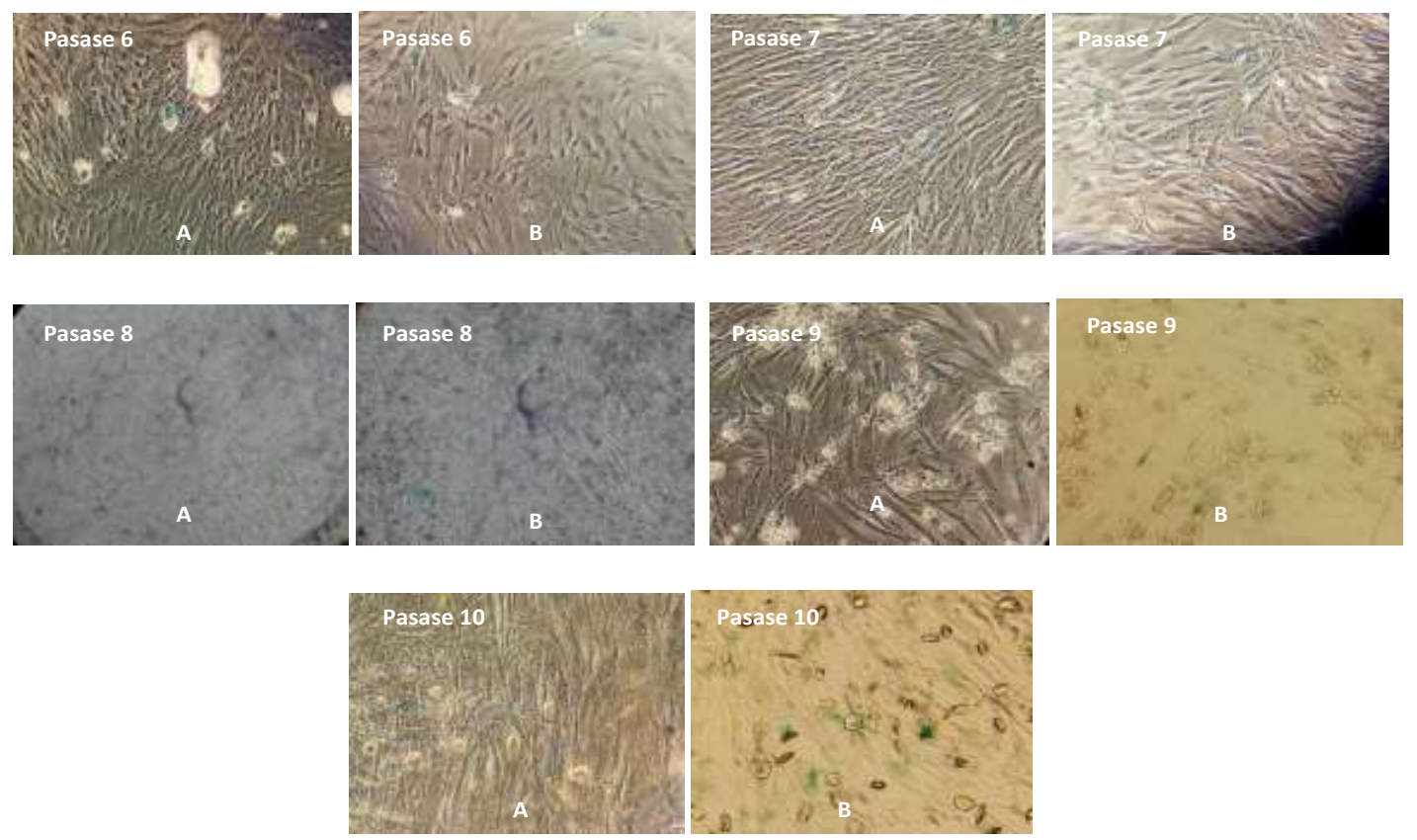

Gambar 2. Pemeriksaan ICC pada ekspresi sel senescence P6 hingga P10 pada kondisi hipoksia (A) dan normoksia (B). Tampak perbedaan morforfologi sel senescence kondisi hipoksia dan normoksia, serta ekspresi SA- $\beta$ Gal yang dilihat dari kuat tidaknya warna biru atau biru kehijauan yang dihasilkan. 
Indonesian Journal of Cardiology

Tabel 3. Tabel Hasil Uji Ekspresi Senescence Hipoksia dibandingkan Normoksia

\begin{tabular}{cccccc}
\hline & \multicolumn{2}{c}{ Hipoksia } & \multicolumn{2}{c}{ Normoksia } & \multirow{2}{*}{ Siq (P-Value) } \\
\cline { 2 - 5 } P6 & Min-Max & Mean \pm SD & Min-Max & Mean \pm SD & \\
P7 & $3.37-4.94$ & $3.75 \pm 0.98$ & $5.86-11.11$ & $7.86 \pm 2.10$ & 0,004 \\
P8 & $2.67-5.56$ & $4.31 \pm 1.32$ & $7.10-10.43$ & $8.88 \pm 1.42$ & 0,001 \\
P9 & $4.29-14.25$ & $7.14 \pm 4.04$ & $39.83-44.39$ & $41.71 \pm 1.94$ & 0,009 \\
P10 & $20.98-37.50$ & $28.5 \pm 6.96$ & $36.82-53.49$ & $43.03 \pm 7.07$ & 0,013 \\
\hline
\end{tabular}

${ }^{*}$ Data dinyatakan bermakna jika nilai $\mathrm{p}<0,005$.

\section{Ekspresi Oct-4 Hipoksia vs Normoksia}

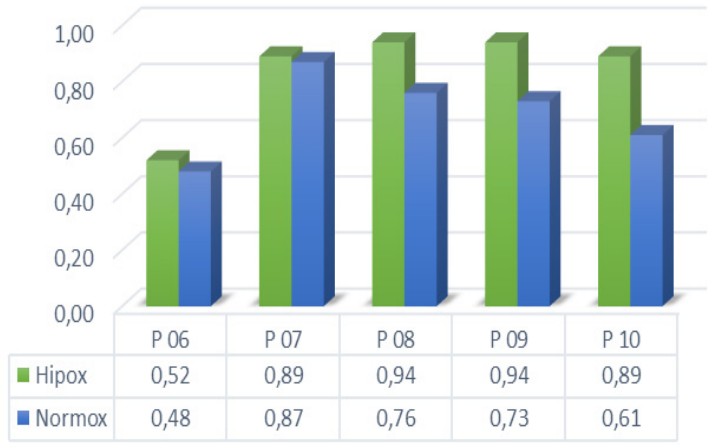

Grafik 2. Perbandingan Ekspresi Oct-4 Hipoksia dan Normoksia Mulai P6 hingga P10

Tabel 4. Tabel Deskriptif Ekspresi Oct-4

\begin{tabular}{ccccc}
\hline & \multicolumn{4}{c}{ Ekspresi Oct4 } \\
\cline { 2 - 5 } & \multicolumn{2}{c}{ Hipoksia } & \multicolumn{2}{c}{ Normoksia } \\
\cline { 2 - 5 } & Min-Max & Mean \pm SD & Min-Max & Mean \pm SD \\
\hline P6 & $0,32-0,68$ & $0,52 \pm 0,13$ & $0,33-0,61$ & $0,48 \pm 0,10$ \\
P7 & $0,80-0,92$ & $0,89 \pm 0,05$ & $0,77-0,94$ & $0,87 \pm 0,06$ \\
P8 & $0,93-0,96$ & $0,94 \pm 0,01$ & $0,52-0,85$ & $0,76 \pm 0,13$ \\
P9 & $0,89-0,98$ & $0,94 \pm 0,03$ & $0,52-0,86$ & $0,73 \pm 0,14$ \\
P10 & $0,82-0,97$ & $0,89 \pm 0,05$ & $0,54-0,68$ & $0,61 \pm 0,06$ \\
\hline
\end{tabular}

\section{Ekspresi Oct-4}

Ekspresi Oct-4 diamati dengan mikroskop fluorescence dengan pendaran IF (immunofluorescence) warna hijau. Didapatkan pendaran IF Oct-4 yang kuat pada pasase dalam kondisi hipoksia dibandingkan normoksia. Sebagian besar pasase kondisi hipoksia, terutama pada P8 menunjukan ekspresi Oct-4 yang lebih tinggi dibandingkan normoksia, yaitu 0,93 hingga 0,96 (rata-rata 0,95); dibandingkan kondisi normoksia 0,52 hingga 0,85 dengan rata-rata 0,76 (Tabel 4 ). Dengan kata lain, pasase dengan ekspresi senescence yang lebih rendah akan menunjukkan suatu ekspresi Oct-4 yang lebih tinggi. Meskipun secara statistik, tidak ada perbedaan bermakna ekspresi Oct-4 kondisi hipoksia dibandingkan normoksia pada P6 (Tabel 5)

\section{Diskusi}

Adipose-Derived Mesenchymal Stem Cell (AMSCs) memiliki banyak antigen permukaan (surface marker) pada selnya untuk menunjukkan sifat atau karakter dari sel tersebut. AMSCs tidak dapat diidentifikasikan dengan menggunakan surface marker tunggal namun diperlukan beberapa penanda untuk identifikasi dari populasi yang ada. Hasil identifikasi surface marker AMSCs pada penelitian ini menunjukkan ekspresi positif CD44 dan CD90 serta tidak terekspresinya CD45 pada pemeriksaan flowcytometry. Semua AMSCs menunjukkan pola karakteristik mesenkimal ekspresi surface marker termasuk CD90, CD105, CD44H, CD73, dan negatif untuk marker hematopoietik seperti CD11a, CD33, CD45, GlycophorinCD235a dan HLA$\mathrm{DR}^{19}$. Kemudian, hasil pemeriksaan karakteristik MSCs secara IF CD90+ dan CD 105+ menunjukkan hasil adanya sel yang berpendar warna hijau sebagai marker karakterisasi fenotipe AMSCs, selain itu pemeriksaan flowcytometri CD 90+ mengekspresikan sel. Sedangkan pada pemeriksaan karakterisasi fenotipe IF MSCs, pemeriksaan CD 45- menunjukkan hasil ekspresi negatif dan didukung oleh pemeriksaan flowcytometri. Hal ini membuktikan bahwa sel yang dikultur adalah benar AMSCs sesuai kriteria ISCT ${ }^{18}$.

Sel senescence mengalami penghentian pertumbuhan yang ireversibel tetapi terus aktif secara metabolik. Secara morfologi menunjukkan perubahan berupa ukuran yang lebih besar, pipih, granularitas yang lebih 
tinggi, perubahan ekspresi gennya dan perubahan rasio nukleus terhadap sitoplasma, serta didapatkan aktivitas dari SA- $\beta$-gal. Perubahan morfologis tidak menggambarkan tahapan dari senescence tetapi menggambarkan perubahan lebih lanjut dalam AMSCs jangka panjang 20,21 . Penelitian kami mengamati perbandingan ekspresi senescence pada kondisi normoksia dan hipoksia, didapatkan hasil penelitian berupa ada perbedaan bermakna ekspresi senescence pada kondisi hipoksia dibandingkan dengan normoksia dengan nilai $p<0,05$. Strategi prakondisi hipoksia terbukti dapat menghambat proses senescence yang dapat dilihat terutama pada pasase lanjut, misal pada P10 tampak masih banyaknya sel-sel AMSCs yang masih survive dengan memperhatikan morfologi selnya (Gambar 2). Selain itu, didapatkan pula hasil ekspresi senescence yang lebih rendah pada kondisi hipoksia dibandingkan dengan normoksia (Tabel 2).

Hal ini sesuai dengan penelitian oleh Lee ChangWoo, et al tahun 2018 yang menyebutkan bahwa prakondisi hipoksia secara signifikan mempercepat laju proliferasi dan memperpanjang rentang hidup MSC dibandingkan dengan normoksia. Dalam kondisi hipoksia, MSC pada pasase lanjut akan terus menerus berproliferasi dan mempertahankan morfologi yang sama dengan sel pasase awal. Namun, pada MSC pasase lanjut (pasase 8 dan seterusnya) dalam kondisi normoksia hampir sepenuhnya kehilangan kemampuan proliferasinya dan bentuknya menjadi pipih, membesar dan berhenti berproliferasi, yang memanifestasikan karakteristik dari senescence dan menunjukkan bahwa hipoksia memperpanjang rentang hidup proliferasi sel MSC, walaupun penyebab pastinya masih perlu penelitian lebih lanjut. Perbedaan penelitian ini dengan penelitian kami adalah source MSC yang digunakan ${ }^{22}$. Lee Chang-Woo et al menggunakan MSC yang berasal dari umbilical cord manusia, sedangkan penelitian kami menggunakan adiposa. Sebuah penelitian yang membandingkan perbedaan antara karakteristik biologis dasar MSC yang berasal dari jaringan adiposa (AMSCs) dan umbilical cord-derived mesenchymal stem cells (UCMSCs) adalah serupa satu sama lain, dan keduanya memiliki kapasitas self-renewal yang kuat, kapasitas antiapoptotik, dan kapasitas multidiferensiasi ${ }^{23}$.

Marker alternatif berguna dalam menilai senescence seluler karena marker-marker ini menunjukkan fungsi biologis yang berlawanan dibandingkan dengan senescence, penurunan regulasi dari faktor transkripsi yang berhubungan dengan pluripotensi dapat menjadi marker potensial senescence pada stem cells ${ }^{24}$. Gen pluripotensi, seperti OCT-4, SOX2, dan Nanog, telah terbukti diekspresikan pada MSC dimana Oct-4 sebagai pengatur utama dari pluripotensi. Pada penelitian ini diamati ekspresi dari Oct-4 untuk mengkonfirmasi terjadinya potensi diferensiasi pada sel AMSCs yang mengalami hambatan proses senescence. Ekspresi Oct-4 berupa pendaran IF warna hijau yang dinilai berdasarkan kuat tidaknya IF pada kondisi hipoksia maupun normoksia. Didapatkan hasil penelitian berupa ekspresi Oct-4 pada kondisi hipoksia lebih tinggi daripada normoksia, dimana semakin lanjut pasase AMSCs pada hipoksia maka ekspresi Oct-4 akan semakin tinggi pula. Sebagian besar pasase pada kondisi hipoksia, terutama pada P8 menunjukan ekspresi Oct-4 yang lebih tinggi kondisi normoksia (Tabel 4). Dengan kata lain, pasase dengan espresi senescence yang lebih rendah akan menunjukkan suatu ekspresi Oct-4. IF pada kondisi hipoksia rata-rata menunjukkan pendaran warna hijau yang lebih kuat daripada normoksia. Meskipun secara statistik, tidak ada perbedaan bermakna ekspresi Oct4 kondisi hipoksia dibandingkan normoksia pada P6 (Tabel 5.15). Hal ini sesuai dengan penelitian oleh

Tabel 5. Tabel Hasil Uji Ekspresi Oct-4 Kondisi Hipoksia dibandingkan Normoksia

\begin{tabular}{cccccc}
\hline & \multicolumn{2}{c}{ Hipoksia } & \multicolumn{2}{c}{ Normoksia } & Siq (P-Value) \\
\cline { 2 - 5 } & Min-Max & Mean \pm SD & Min-Max & Mean \pm SD & 0,646 \\
P6 & $0,32-0,68$ & $0,52 \pm 0,13$ & $0,33-0,61$ & $0,48 \pm 0,10$ & 0,009 \\
P7 & $0,80-0,92$ & $0,89 \pm 0,05$ & $0,77-0,94$ & $0,87 \pm 0,06$ & 0,009 \\
P8 & $0,93-0,96$ & $0,94 \pm 0,01$ & $0,52-0,85$ & $0,76 \pm 0,13$ & 0,030 \\
P9 & $0,89-0,98$ & $0,94 \pm 0,03$ & $0,52-0,86$ & $0,73 \pm 0,14$ & 0,0001 \\
P10 & $0,82-0,97$ & $0,89 \pm 0,05$ & $0,54-0,68$ & $0,61 \pm 0,06$ & 0 \\
\hline
\end{tabular}

*Data dinyatakan bermakna jika nilai $\mathrm{p}<0,005$. 

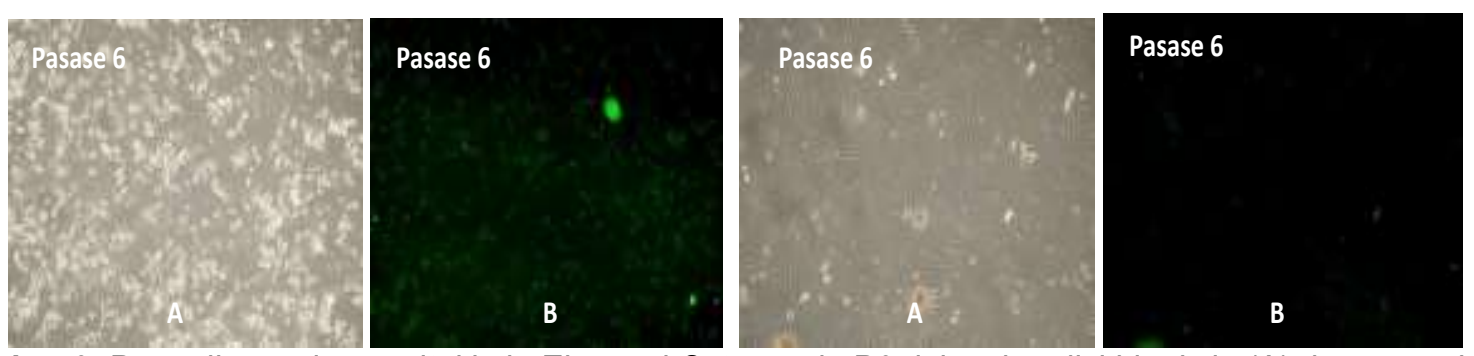

Gambar 3. Pemeriksaan imunositokimia Ekspresi Oct-4 pada P6 dalam kondisi hipoksia (A) dan normoksia (B)
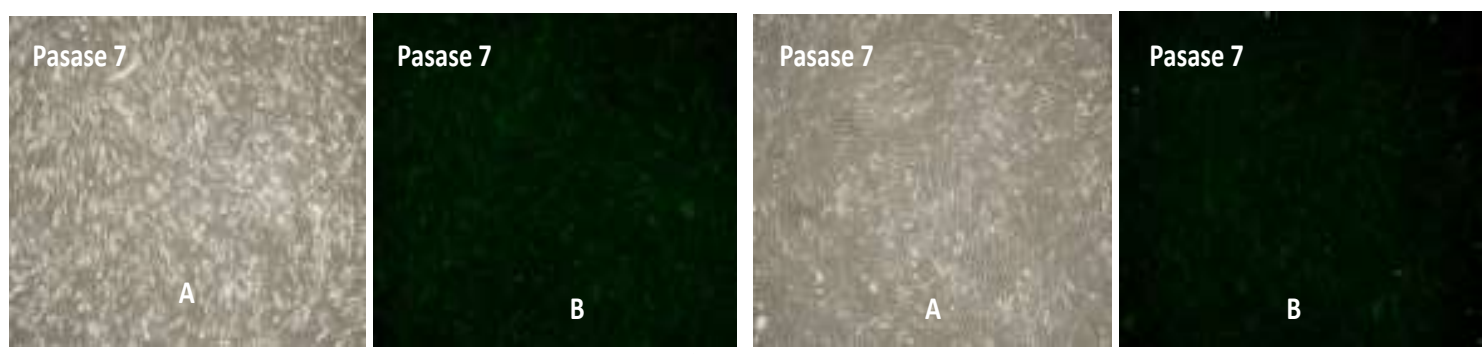

Gambar 4. Pemeriksaan imunositokimia Ekspresi Oct-4 pada P7 dalam kondisi hipoksia (A) dan normoksia (B)
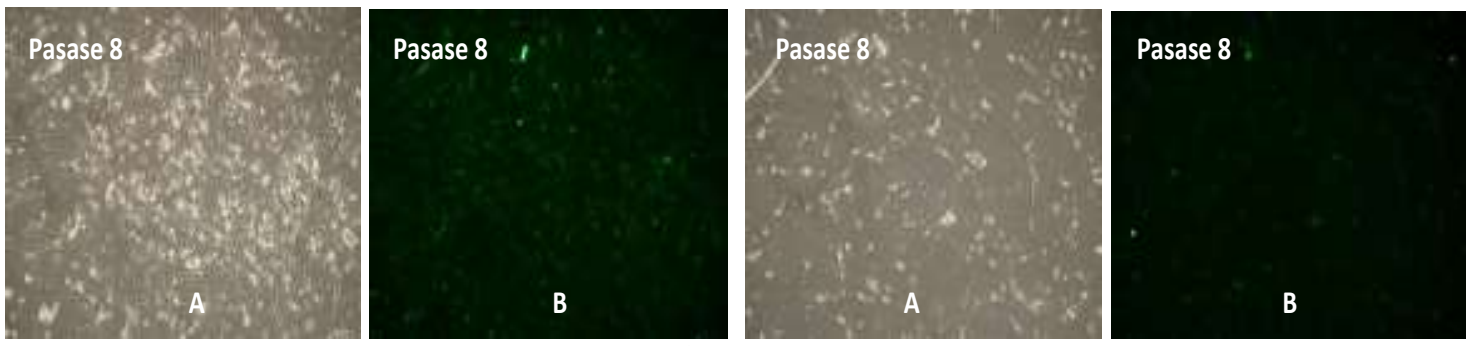

Gambar 5. Pemeriksaan imunositokimia Ekspresi Oct-4 pada P8 dalam kondisi hipoksia (A) dan normoksia (B)
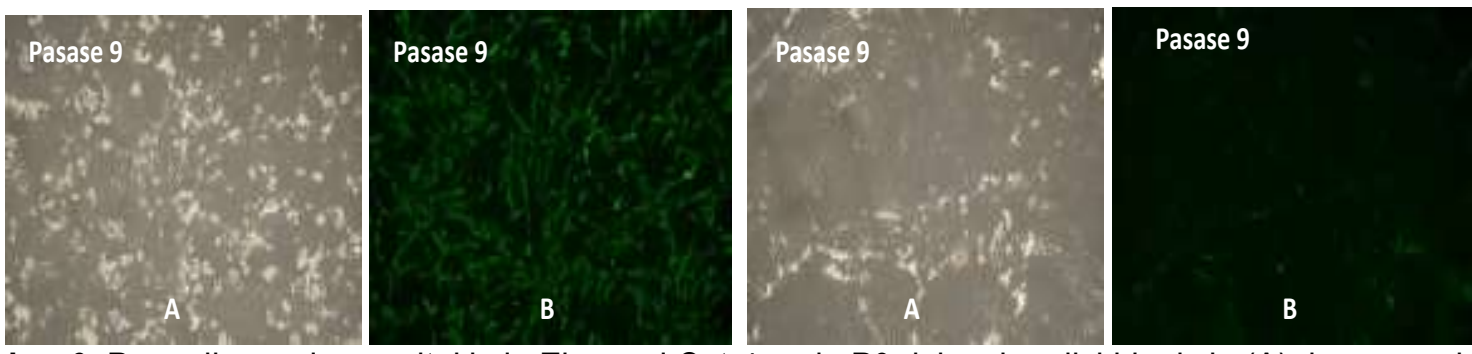

Gambar 6. Pemeriksaan imunositokimia Ekspresi Oct-4 pada P9 dalam kondisi hipoksia (A) dan normoksia (B)
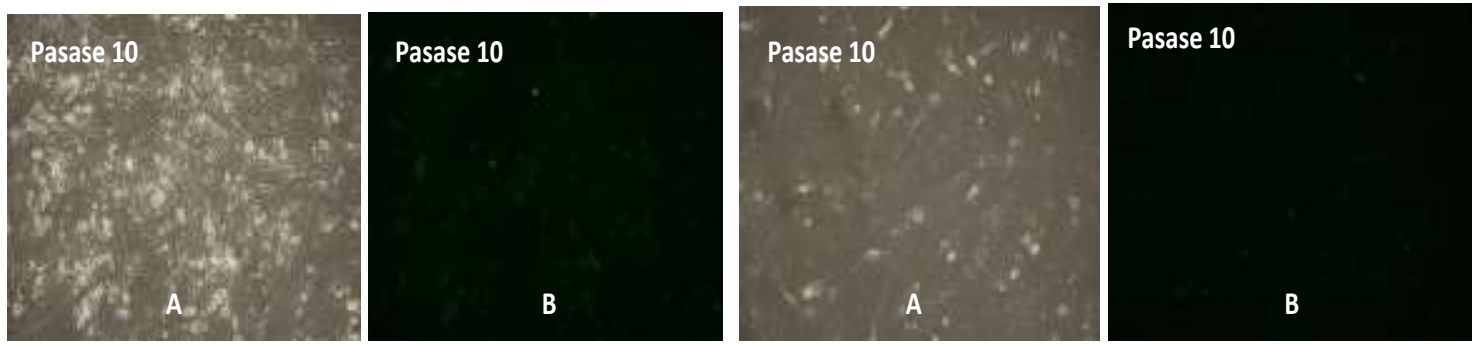

Gambar 6. Pemeriksaan imunositokimia Ekspresi Oct-4 pada P10 dalam kondisi hipoksia (A) dan normoksia (B) 
Piccinato et al tahun 2015 yang membuktikan bahwa dalam kondisi hipoksia, MSC dengan ekspresi Oct-4 yang tinggi terdapat pada sel yang rentang hidupnya panjang. Rasio Oct-4/p16 yang tinggi berhubungan dengan peningkatan rentang hidup. Penelitian Piccinato ini merupakan studi pertama yang menunjukkan hubungan gen pluripotensi dengan proses senescence dan rentang hidup suatu MSC. Piccinato et al mengemukakan bahwa tingkat p16 yang rendah dan tingginya ekspresi Oct-4 dapat memprediksi keadaan senescence dan potensi diferensiasi MSC pasase awal in vitro. Mekanisme yang mendasari hal ini adalah adanya pengikatan langsung Oct-4 ke promotor DNA methyltransferase 1 , sehingga meningkatkan ekspresinya yang pada akhirnya akan menurunkan ekspresi p16 dan p21 serta mempertahankan DNA methylation, yang pada akhirnya dapat mengatur status proliferatif dan MSC yang tidak terdiferensiasi. DNA methylation adalah proses dimana grup methyl ditambahkan pada molekul DNA. Methylation dapat mengubah aktivitas segmen DNA tanpa mengubah urutannya, ketika diletakkan pada gen promotor, DNA methylation akan menekan transkripsi gen ${ }^{25}$.

\section{Kesimpulan}

Dari penelitian kami, dapat disimpulkan bahwa prakondisi hipoksia selain dapat menghambat proses senescence juga terbukti dapat meningkatkan potensi diferensiasi pada AMSCs terutama pada pasase lanjut yaitu P8 dan selanjutnya.

\section{Daftar Singkatan}

AMSCs : Adipose-Derived Mesenchymal Stem Cell $\mathrm{CD}$ : Cluster of Differentiation

DNA : Deoxyribonucleic

DR : death receptor

FC : FlowCytometry

ICC : Immunocytochemistry

IF : immunofluorescent

ISCT : International Society of Cellular Therapy

Oct- 4 : Octamer-4

PI3K : phosphatidylinositol 3-kinase

SA- $\beta$ Gal :Senescence-Associated $\beta$-Galactosidase

WHO : World Health Organization

\section{Persetujuan Etik}

Penelitian ini adalah hasil karya sendiri, dan semua sumber yang dikutip maupun dirujuk telah dinyatakan dengan benar dan telah lolos laik etik, dengan nomor sertifikat etik : 0374/KEP/VII/2018.

\section{Persetujuan untuk Publikasi}

Para penulis artikel ini memberikan izin kepada Jurnal Kardiologi Indonesia untuk menerbitkan artikel ini jika artikel ini diterima.

\section{Konflik Kepentingan}

Tidak ada konflik kepentingan dalam pelaksanaan penelitian ini.

\section{Pendanaan}

Pendanaan penelitian ini berasal dari dana pribadi peneliti.

\section{Daftar Pustaka}

1. Seshadri S, Beiser A, Emberson JR, Whincup PH, Morris RW. 2010. Lipid Modification : Cardiovascular Risk Assessment and the Modification of Blood Lipids for The Primary and Secondary Prevention of Cardiovascular Disease. NHS National Institute for Health and Clinical Excellence.

2. Fuster V, Walsh R, Harrington R. Preventive Strategies For Coronary Artery Disease; Introduction. In: Hurst's The Heart. 13th ed. Unites States; 2011.

3. Williams AR, Hare JM. Mesenchymal Stem Cell: Biology, Pathophysiology, Translation Findings, and Therapeutic Implications for Cardiac Disease. Circulation. 2011;109:923-40.

4. Lim SY, Dilley RJ, Dusting GJ. Cytoprotection and Preconditioning for Stem Cell Therapy. In: Advances in Regenerative Medicine. 2011;5:89-118.

5. Sun Q, Zhang Z, Sun Z. 2014. The potential and challenges of using stem cells for cardiovascular repair and regeneration. Genes Dis. ; 1(1): 113-9.

6. Elnakish MT, Hassan F, Dakhlallah D, Marsh CB, Alhaider IA, and Khan M. 2012. Mesenchymal 
Stem Cells for Cardiac Regeneration: Translation to Bedside Reality. Volume 2012, Article ID 646038.

7. Porada CD, Zanjani ED, Almeida-Porada G. Adult Mesenchymal Stem Cell: A Pluripotent Population With Multiple Applications. Curr Stem Cell Res \& Therapy Vol 1(3); 2006.

8. Geng YJ. Molecular Mechanisms for Cardiovascular Stem Cell Apoptosis and Growth in the Hearts with Atheroscerotic Coronary isease and Ischemic Heart Failure. Science. Ann NY Acad. 2003;1010:687-97.

9. Hadjipanayai E, Schiling AF. Hypoxia-based Strategies for Angiogenic Induction-The Dawn of a new Era for Ischemia Therapy and Tissue Regeneration. In: Organogenesis. 2013;9:1-12.

10. Sart S, Ma T, Li Y. Preconditioning Stem Cells for In Vivo Delivery. Bioresearch Open Access. 2014;3: 137-49.

11. Chen J, Patschan S, Goligorsky MS. Stress-induced premature senescence of endothelial cells. J Nephrol. 2008;21(3):337-44.

12. Su T, Dan S, Wang Y. Akt-Oct4 Regulatory Circuit in Pluripotent Stem Cells. In: Chinese Science Bulletin. 2014;59(10): 936-942.

13. Dulic V. Senescence Regulation by mTOR. Methods Mol Biol. 2013;965:15-35.

14. Voncken JW, Niessen H, Neufeld B, Rennefahrt U, Dahlmans V, Kubben N, et al. MAPKAP kinase $3 \mathrm{pK}$ phosphorylates and regulates chromatin association of the pol-ycomb group protein Bmil. J Biol Chem. 2005;280(7):5178-87.

15. Legzdina D, Romanauska A, Nikulshin S, Kozlovska T, Berzins U. Characterization of Senescence of Culture-expanded Human Adipose-derived Mesenchymal Stem Cells. International Journal of Stem Cells. 2016; 9(1):124-36.

16. Gerland LM, Peyrol S, Lallemand C, Branche R, et al. Association of increased autophagic inclusions labeled for b-galactosidase with fibroblastic aging. Experimental Gerontology. 2003;38:887-95.

17. Zeineddine D, Hammoud AA, Mortada M, Boeuf $\mathrm{H}$. The Oct4 protein: more than a magic stemness marker. Am J Stem Cells. 2014;3(2):74-82

18. Dominici et al. Minimal criteria for defining multipotent mesenchymal stromal cells. The International Society for Cellular Therapy position statement. International Society for Cellular Therapy. Cytotherapy. 2006; 8(4):315- 17.
19. Trivanovi D, Nikoli S, Krsti J, Jaukovi A, Mojsilovi $S$,et al. Characteristics of human adipose mesenchymal stem cells isolated from healthy and cancer affected people and their interactions with human breast cancer cell line MCF-7 in vitro. Cell Biol Int. 2014;38:254-65.

20. Turinetto V, Vitale E, and Giachino C. Senescence in Human Mesenchymal Stem Cells: Functional Changes and Implications in Stem Cell-Based Therapy. Int. J. Mol. Sci. 2016;17:1164.

21. Choo KB, Tai L, Hymavathee KS, Wong CY, Nhi Nguyen PN, et al. Oxidative Stress-Induced Premature Senescence in Wharton's Jelly Derived Mesenchymal Stem Cells. Int. J. Med. Sci. 2014; 11(11):1201-07.

22. Lee CW, Kang D, Kim AK, Kim DY, Kim DI. Improvement of Cell Cycle Lifespan and Genetic Damage Susceptibility of Human Mesenchymal Stem Cells by Hypoxic Priming. International Journal of Stem Cells. 2018;11(1):61-67.

23. Hu L, Hu J, Zhao J, Liu J, Ouyang W, et al. Side-by Side Comparison of the Biological Characteristics of Human Umbilical Cord and Adipose Tissue-Derived Mesenchymal Stem Cells. BioMed Research International. 2013; 1-12.

24. Tsai CC, Su PF, Huang YF, Yew TL, and Hung SC, "Oct4 and Nanog directly regulate Dnmt1 to maintain selfrenewal and undifferentiated state in mesenchymal stem cells," Molecular Cell. 2012; 47(2):169-82.

25. Piccinato CA, Sertie AL, Torres N, Ferretti M, and Antonioli E. High OCT4 and Low p16INK4A Expressions Determine In Vitro Lifespan of Mesenchymal Stem Cells. Stem Cell International. 2015; $1-11$. 